\title{
Do Price Incentives Work in Incomplete Food Agricultural Marketing Systems? A Case Study in the Hohoe District, Ghana
}

\author{
Togbiga Dzivenu \\ Faculty of Integrated Development Studies \\ University for Development Studies \\ Wa Campus, Ghana \\ Email: tdzivenu@yahoo.com \\ DOI: http://dx.doi.org/10.4314/gjds.v11i1.3
}

\begin{abstract}
The debate on low subsistence smallholder food agricultural production in Ghana in particular and sub-Saharan Africa in general largely blamed supply-side constraints. Policy prescriptions advocating sector reforms and transformation consequently focused on supply-side solutions and only acknowledged demand-side limitations. Presumed in strategy-choices was subsistence food producers would necessarily respond to price incentives to increase food productivity. This paper interrogates the link between price incentives and increased subsistence food productivity in rural agricultural marketing systems by examining issues in subsistence agriculture in Hohoe District of Ghana. Findings revealed that a sustained expanded food production output is a function of demand and supply. A critical incentive to a sustained expanded food production output by way of making food agriculture a poverty reduction tool is, therefore, a sustained increase in output demand. The paper concludes that price incentives do not work in incomplete food agricultural marketing systems. Implied is that making food agriculture an effective poverty reduction tool requires both medium - and long-term state-led investments in processing and food market outlet development. This position revives the argument that the role of the state in an economy cannot be eliminated as has been proven in more fully developed western agricultural markets. As such, any free-market policy that aims at boosting food agriculture productivity must necessarily go simultaneously with the development of food agricultural output markets.
\end{abstract}

Key words: Food agriculture, Price incentives, Marketing systems, Productivity, Policy. 


\section{Introduction}

Food agriculture is chiefly a subsistence smallholder activity in Ghana. Being the most labour-intensive sector of the economy and main source of livelihood for rural households, it employs about 60 percent of economically active rural population. The hoe and cutlass (machete) are the main farming tools and about 90 percent of farm holdings are less than two hectares in size-rendering the farming system virtually traditional (MoFA, 2010). Though mechanized and bullocks farming are also practised, these operate on a lesser scale. Food agricultural production is mainly rain-fed. Development of irrigated farmlands is slow and inadequate as land area under irrigation is only 0.2 percent of the 57.1 percent representing total available arable land area (MoFA, 2010). Although subsistence smallholder food production output satisfies 80 percent of Ghana's domestic food needs, food productivity is still considered low due to low returns on farmer-output (MoFA, 2009). As such, a farmer may be food secure but not self-sufficient.

Studies on low subsistence smallholder food agricultural productivity tend to focus mainly on a host of supply-side factors. Key factors taking the blame include farmerdisincentives ascribed to food price distortions, low labour productivity and crop yield, low technology adoption rate, inauspicious agricultural institutional frameworks, and inefficient resource-use (Sikod, 2003; Sarris, Savastano \& Christiansen, 2006). Other constraints often cited but glossed over include inaccessible food agricultural markets and poor rural infrastructure (road access and irrigation) (MoFA, 2007). Policy responses to distortions to farmer incentives and food prices were prescriptions for policy reform and transformation of subsistence smallholder food agricultural sector. Taken together, the objects were two-fold: removing existent distortions weakening farmer-incentive framework and strengthening agricultural institutions to create an enabling environment for sector growth. This imputes the low food agricultural productivity to government interventions and the aim of the reform was to enlist private sector participation in agriculture. In concert, this was to inspire food market efficiency and competitiveness to improve farmer-incentive structure (Poulton, Kydd \& Dorward, 2006). Agricultural sector policy reform packages have accordingly been implemented since the mid-1980s to remove targeted distortions to farmer incentives and food prices.

Central elements of the sector reform programme were 'getting prices right' through structural adjustment and 'getting institutions right' through governance projects (Harrison, 2005; Bates, 1981). Implementation involved dissolution of food marketing boards and withdrawal of farm-input subsidies to remove distortions to food agricultural incentives to enhance food productivity (World Bank, 2008). As it turned out, the prescribed solutions for the low sector productivity focused mainly on providing solutions for the supply-side factors while merely acknowledging the demand-side limitations. Veiled in the agenda were imagined boosting of market efficiency and reduction of costs to public agencies (Poulton et al., 2006). Of interest is the shift in policy orientation from government sector control to greater reliance on market forces of demand and supply and private sector participation to boost market efficiency. Supporting the strategy choice was 
the assumption that food producer prices were the real determinants of food productivity and farmer incomes (Riley \& Staatz, 1993). Germane to this belief is that public sector participation in the food market had crowded out private sector participation and distorted food market efficiency (Poulton et al., 2006). Anticipated in the reform package was, therefore, an unprompted development of efficient food agricultural marketing systems to guarantee dynamic food marketing performance and vibrant rural sector (Nwanze, 2010).

Against this backdrop, this paper examines the link between price incentives and increased food agricultural productivity in rural food agricultural marketing systems. In other words, the paper seeks to explain the low subsistence smallholder food agricultural productivity in the nature of the existing rural food agricultural marketing systems in Ghana. Understanding the issues is critical to informing future action programmes designed to improving performance of food production system in Ghana in particular and sub-Saharan Africa (SSA) in general. The paper is built on primary data collected from the Hohoe District in the Volta Region of Ghana vis-a-vis the implemented liberalised agricultural strategies to get prices and institutions right. It presents the experience gathered after the implementation of the Medium-Term Agricultural Development Programme (MTADP) spanning the mid-198os and mid-199os. Thus, the food agricultural sector component of the implemented structural adjustment programme was the MTADP. As well, the term market as used in this paper refers to the existence or putting in place public and private institutions that support free market activities. It does not allude to or advocate statutory monopolies in food output and input markets.

The paper is divided into five parts. Immediately following this introductory part is a review of the methodology of the study. The next outlines Ellis' (1993) characterisation of subsistence production and features similarities with the nature of subsistence smallholder food agricultural production existing in the Hohoe District. Part four assesses the general reform policy effects on smallholder food agricultural production in the District. Finally, the paper examines the rural agricultural marketing systems facing food agricultural producers in the Hohoe District in line with the policy prescriptions.

\section{Methodology}

The study drew on multiple qualitative methods in investigating the link between price incentives and increased food agricultural productivity in incomplete food agricultural marketing systems. These include interview schedules, personal and focus group interviews and participant mapping. A study population of 2000 subsistence food crop producers working on various projects in the Hohoe District was the target group. Considered for study were a sample size of 300 subsistence smallholder farmers, 30 senior government officials at both national and district/community levels having decisionmaking responsibilities, and 10 opinion leaders comprising two each from the selected five communities. Opinion leaders identified and interviewed were award winning 
district chief farmers, formal and informal leaders - men and women of various age categories engaged in agriculture and located in the selected communities for purposes of triangulation. The study was conducted on three separate occasions. The first one was carried out between 9th and 29th March 2003 just after the first rains in the District. A second visit was undertaken between 16th and 19th December 2010. There was a third visit on 4th and 5th February 2012 while revising this paper.

The District comprises 13 urban, peri-urban and rural-rural traditional areas. The study randomly selected five traditional areas composed of 60 percent rural and 40 percent periurban areas. Representing the 60 percent rural traditional areas were Akpafu, Fodome, and Leklebi while the $40 \%$ peri-urban areas were Gbi and Ve. Five communities were further randomly selected from the chosen five traditional areas. The 60 percent rural communities were Akpafu-Odomi, Fodome-Xelu, and Leklebi-Agbesia and the 40 percent peri-urban areas were Gbi-Wegbe and Ve-Koloenu. A total of 300 hundred respondents were also randomly selected from 300 households using their house numbers in each case. Since all these farmers worked on similar farm projects, they represented a homogenous study group prompting the choice of cluster-sampling techniques. Using open - and close-ended interview schedules, 154 males and 146 females were interviewed at first, representing 51.3 percent and 48.7 percent respectively to achieve $100 \%$ responses ${ }^{1}$. The imbalance was later corrected during a second visit to triangulate findings during a twosession focus group interviews-one in rural-rural and one in peri-urban community. Each focus group had two men and six women to make up for the initial imbalance. As found out, the best time for field research in the District should be between the months of December and February when most farmers do not have much work on their farms.

\section{Profile of Hohoe District}

The Hohoe Municipal District in the Volta Region of Ghana was selected for the empirical component of this study. It is currently one of the 25 administrative units of the region. It is located within longitude $\circ^{\circ} 15^{\prime} \mathrm{E}$ and $\mathrm{o}^{\circ} 45^{\prime} \mathrm{E}$ and latitude $6^{\circ} 45^{\prime} \mathrm{N}$ and $7^{\circ} 15^{\prime} \mathrm{N}$. It is bounded on the east by the Republic of Togo, on the northwest by Jasikan District, on the west by Kpando District and on the south by Ho Municipal District. It covers a total land area of 117200 ha or 1172 square kilometres representing 5.6 percent of the regional land size and 0.5 percent of the national land area. Located in the forest-savannah transitional ecological zone, the District straddles two ecological zones and so belongs to Ghana's designated food production zone. The District has a bimodal rainfall pattern characterised by major and minor rainy seasons. The major season starts from April through July while the minor one lasts from September through November. Though the rainfall pattern is bimodal, it sometimes rains continuously from April through November. Its bimodal nature instituted two farming seasons. Total annual rainfall ranges between $1100 \mathrm{~mm}$ and

1 Usually after the first two rains, farmers were mostly out during the day clearing the land for planting. The best time for meeting anybody home was by late afternoon; even so, most women were busy attending to evening family meals and so not readily available for interviewing. 
$1500 \mathrm{~mm}$ averaging $1300 \mathrm{~mm}$. Cultivation periods flit around 200 and 220 days which are long enough to grow all types of food crops.

Literacy rate among farmer respondents was high. Save for only 6.7 percnet who did not receive any formal education, 93.3 percent of respondents received some formal education including two percent that had a tertiary education. Since the inception of the National Farmers Day celebration, the District has produced six national award winners for vegetable production.

\section{Food Crops Selected for the Study}

Food crops selected for this study were maize, rice and cassava. One reason for their selection is that they are general staples in the country. Besides, maize and rice are particularly important in calorie supply to Ghanaian households and government targeted increases in their production in the MTADP document. The intention was meeting 80 percent of the country's domestic needs for maize, 60 percent for rice and be self-sufficient in cassava production. Evidence, however, shows that production of these crops was location-specific determined by land size allocated to producing a particular crop in a clearly defined traditional area (Dzivenu, 2005). Crops specific to particular traditional areas received largest land size allocations vis-a-vis total land area under cultivation in the area and this demonstrates crop importance to the specific area.

Maize, for example, was the most important food crop produced in the District. As such, maize had the largest land area of 5150 ha, representing 30.4 percent of the total land size under cultivation. Ranking next to maize was cassava with 26.5 percent, representing 4500 ha followed by rice with 20.6 percent or 3500 ha (see Table 1 ). Other food crops grown to supplement household food needs were plantain, vegetables, cocoyam and fruits, constituting 22.5 percent. These were considered minor food crops and were hardly sold. Also established was that major food crops committed to largest land sizes served both as staples and major sources of farm revenue in the designated communities. As confirmed by 88.5 percent of respondents in Akpafu-Odomi, rice was both a staple and a major source of farm revenue. Hence, in Akpafu-Odomi, rice production had the largest land size of 68.5 ha while maize production had 37.5 ha. Though maize and cassava appear ubiquitous, they are specific to Fodome-Xelu, Ve-Koloenu and Leklebi-Agbesia in varying degrees (see Table 2).

Table 1: Major Food Crop producing Areas in the Hohoe Municipality

\begin{tabular}{|l|l|l|l|}
\hline Crops & $\begin{array}{l}\text { Area under } \\
\text { Cultivation (ha) }\end{array}$ & Percentage & Major Producing Areas \\
\hline Maize & 5150 & 30.4 & Fodome, Liati, Gbledi, Ve, Wli, Alavanyo \\
\hline Cassava & 4500 & 26.5 & $\begin{array}{l}\text { Fodome, Ve, Alavanyo, Nyagbo, Tafi, } \\
\text { Akpafu }\end{array}$ \\
\hline
\end{tabular}




\begin{tabular}{|l|l|l|l|}
\hline Rice & 3500 & 20.6 & $\begin{array}{l}\text { Akpafu, Santrokof, Lolobi, Likpe, } \\
\text { Godenu, Gbi-Wegbe }\end{array}$ \\
\hline Yam & 1600 & 9.4 & Ve, Alavanyo, Tafi \\
\hline Plantain & 400 & 2.4 & Alavanyo, Likpe, Akpafu, Logba \\
\hline Vegetables & 1470 & 8.6 & Ve, Nyagbo, Tafi \\
\hline Fruits & 350 & 2.1 & Nyagbo, Logba \\
\hline Total & 16,970 & 100 & \\
\hline
\end{tabular}

Source: District MoFA Office and Field data , February 2012

Table 2: Specific Crops and Acreages under Cultivation in the Selected Sub-communities

\begin{tabular}{|l|l|l|l|l|l|}
\hline Crops & Akpafu-Odomi & Fodome Xelu & Gbi-Wegbe & Leklebi Agbesia & Ve-Koloenu \\
\hline & Acreage & Acreage & Acreage & Acreage & Acreage \\
\hline Rice & 68.5 & 4 & 94.5 & 2 & 10.5 \\
\hline Maize & 37.5 & 90 & 58 & 65.5 & 69 \\
\hline Cassava & 25 & 83.5 & 47 & 68 & 70 \\
\hline
\end{tabular}

Source: Field data, February 2012

A critical variable explaining the crop-specificity was geographic location of the traditional area. The geographic location of each traditional area effectively dictated its soil type available for farmer use and crop type suitable to the environment. Rice production was in this way restrictive to only river and valley bottom areas. The ecology similarly created differences in occupational interests and non-farm income sources in the traditional areas. Also playing up the differences in occupational interests was the co-existence of cash and food crop producers in the District. For example, 98 percent of respondents indicated farming as the main occupation. Of this 98 percent, 3.3 percent also grew cocoa alongside. While cash croppers received institutional and input support, the food croppers did not. All these factors taken together created the variability in crop choice decisions, highlighting differences in occupational interests and existence of an internally differentiated' smallholder subsistence farming group in the District (Ellis, 1993).

Five distinct patterns of farming systems exist in the District, exhibiting complex mixed cropping as 87 percent of respondents grew more than one crop on the same bed. For example, maize and cassava were intercropped throughout the District. As the farmers explained, this was to increase farmer output per cultivated unit area. Rice was the only mono-cropped staple. Factors identified as jointly creating differences in the farming 
systems as evidenced by choice of crops grown in each traditional area include the ecological environment and socio-economic needs.

\section{Frank Ellis' Characterisation of Subsistence Production}

Determining the prevailing patterns of agricultural production and consumption relations existent in the Hohoe District requires Ellis' (1993) characterisation of subsistence farming. Relevant characteristics considered here include deciding the dominant economic activity; non-market criteria in land allocation; use of household labour and nature of production and consumption patterns in the District. In which case, farming must be the dominant economic activity of the designated social group, though household members can engage in other secondary non-farm economic activities. Such that land-resource-use forms the basis of livelihood source within the social group and the traditional user right are accessed through the existent inheritance system within the social group. One other measure is the dominant use of household labour in food production or working on the land (Ellis, 1993). However, this does not preclude the sale of household labour as members can sell labour outside the farm on ad hoc basis for purposes of household survival. As well, production is not specialised and is chiefly for autoconsumption resulting in very little or no derived farm income from food commodity markets (Moore, 1993). Profit motive is hardly part of subsistence farming given the thought that the goal of food crop farmers is household reproduction rather than profit maximisation. Against this background of Ellis' categorisation of subsistence farming, we consider the features of food crop production in Hohoe District.

\section{Nature of Food Agriculture Production}

To appreciate the plight of food croppers in Hohoe District requires a better understanding of the issues on ground in terms of production and consumption relations. It is, thus, imperative to establish both existence and level of subsistence production in the District using Frank Ellis' analytical framework. The features of production and relations of consumption in the District were grouped and analysed under the following three broad categories: dominant economic activity, land - and labour-use.

\section{Dominant Economic Activity}

Agriculture is the dominant economic activity within households in Hohoe District as 98 percent of the respondents indicated farming as their main occupation. What is established here is the existence of a small non-farm sector and non-specialised form of production totalling 2 percent. Also implied is the existence of land and household labour as principal factors of food crop production with the basic variable input as household reproductive labour. Though farm practice is subsistence in orientation, most subsistence farmers in the District do regard farming as a form of commercial activity. For instance, 
90 percent of respondents took their being in agriculture as a way of meeting both daily food requirements and family financial commitments. Only 10 percent of respondents took to farming only for purposes of auto-consumption. Seventy percent of respondents engaged in other forms of secondary economic activities essentially to supplement farm income. It also suggests that the main farmer concern is reproduction rather than profit maximisation. In which case, farmer efforts at increasing farm output to make profit merely denote farmer-need-adaptive-strategies in responding to pressing environmental changes (van der Geest \& Dietz, 2004).

Though output was generally limited to subsistence production level, farmer attempts to expand output only demonstrates farmer urge to generate some marketed surplus to afford some extra income. This implies that whatever portion of farm output was sold may not necessarily represent their marketed 'surpluses' but a compulsory requirement to meet other family financial needs. It was in that case not farm-profit but returns to family labour. Household food requirements were also sufficiently met from farmers' own stored home-grown food. As it was, $94 \%$ of respondents subsisted on home-grown food till next harvest and just 6 percent survived on external sources such as community support and remittances. The inference is that unless there was a massive crop failure or bad harvest due to some ecological disaster, these farmers had no need for government food support. It is also indicative of exploitable food export potential of the District, which attractive agricultural policy incentives can translate into reality.

\section{Land-use}

Each social group in the Hohoe District having a common language with similar customary and traditional practices lived within a common geographical area. Land ownership was allodial and vested in families in the District. Family membership was either by birth or absorption. Land was accordingly a social and communal resource and each member of a social group had indisputable and equal usufructuary rights to its occupation and use. These inheritable rights conferred on each holder the power to exercise all rights of land ownership. However, only individual male members of a specific family had this inheritable right and only such individual family members could derive the ownership and land-use rights from that family. Though women had granted land-use interests given upon request, they could not transfer it. The individual land holder was not by any means restricted to any amount of land appropriated for use neither was there any restriction on further sub-division of the inherited land. The nexus is that increases in population size inevitably translated into further sub-division of inherited farmlands resulting in decreasing size of household farmland holdings. Household farmland holding in the District was generally less than one hectare (ha) in size where a hectare equals 2.47 acres.

Survey evidence indicated that 72.5 percent of respondents regarded population pressure as the major factor subdividing and reducing average size of nearby household holdings in the District. This implied walking over longer distances in the fields searching for 
alternative suitable farmlands as 77 percent of respondents indicated. Implicit in the land-use was the expectation that group members would also on their part use the land in conformity with the accepted customary practices. It is remarkable that 83.7 percent of respondents operated on their own farmlands. Of the 83.7 percent, only one percent claimed ownership by purchase. It means 82.7 percent accessed land resource through customary land-inheritance rights existent in various farm communities. The remaining 16.3 percent enjoyed the varying land-use-rental forms obtainable in the District as in sharecropping systems and land lease. In each of the 13 traditional areas, land represented a factor of production that had a price. Thus, the land-use practices obtaining in the District fit Frank Ellis' characterisation of land-use in subsistence food production.

\section{Labour-use}

A key input factor in the District was human labour. In all the 13 traditional areas, tillage was mainly by hoe using household reproductive and hired labour with isolated cases of use of tractor or power tiller machines in land preparation. Though the tractor or power tiller could be hired in the District for use in land preparation, transportation and in some cases threshing, it was in short supply. The point is that as an effective labour substitute, the use of mechanical power in land preparation increases farm size and radically decreases food production costs. However, except for peri-urban farm communities benefiting from their proximity to urban centre, rural-rural farm communities were disadvantaged and depended largely on hired labour. In Akpafu Odomi, for example, there was only one power tiller owned by Bilby Asase, the "2002 District Best Farmer". As noted, he had the largest farm size in the community. Informal interview with farmers identified the short supply of mechanical power as another constraint on food productivity. The practice of bullock farming was non-existent. Further enquiry revealed that food crop production was not linked to concessional credit or marketing arrangements in the District.

Substituting for the subsidy removal on tractor use in the District was the emergence of waged farm-labour-use in subsistence food production. This involved a shift from total dependence on household reproductive labour and labour exchange practices to hired labour in subsistence food production. The evidence shows an increasing dependence on use of casual daily paid wage and contract farm labour for subsistence production manifesting shortage of household reproductive labour throughout the District. Survey evidence shows that 93.7 percent of respondents admitted the use of hired labour in subsistence food production. Only 3.3 percent benefited from traditional practice of exchange labour-use and three percent depended on household reproductive labour. A focus group discussion fingered negative externality of education on agriculture as a key factor reducing household size and prompting the substitution of hired labour in subsistence food production. 
Though the Ghana Living Standard Survey (GLSS 4) indicated a general national decline in rural household sizes from 5.2 in 1984 to 4.6 in 1992 (GSS, 2000), the average household size in the District was 6.5. This compared favourably with the national average. However, of the average size of 6.5 , the computed household size available for farm work in the District was 4.4 representing 67.9 percent. Of this $4.4,2.4$ (37.3\%) of household productive labour was available for farm work for just two days per week. This fraction was the portion of household labour held up in school explaining the negative externality of education on agriculture due to the implemented free compulsory and universal basic education (FCUBE ${ }^{2}$ ) policy (Ghana Government, 1997). It implies that the size of productive labour available for normal household-food-production for more than two days per week was only 2.o or mere 30.7 percent. While the survey did not explore the contributions of the other $2.1(32.1 \%)$ to household income, they may represent those too young for farm work, disabled, learning trade or engaged in some other productive activity. Hired labour had in this way substituted for household productive labour in expanding area under cultivation. Practices of labour market segmentation that induce 'bonded labour' or 'exclusionary arrangements' to support Brass' position were nonexistent in the District (Brass, 1990).

That Hohoe District exhibited all the characteristics of subsistence food production accentuated the existence of subsistence pattern of farming. However, this must be qualified. The pattern of subsistence production seen in the District meant more than just producing for auto-consumption to support life. As observed, there was always a 'little extra' for sale to help meet other basic household non-farm needs. Producing something extra for participation in their local economy confirmed the presence of farmer-profit motive. Similarly, increasing acreage for purposes of output expansion and farmer demand for output market indicated farmer attempts to maximise profit. Evidence of mixed-type of farm management to raise output per cultivated unit area and finding alternative approaches to increasing output in the face of subsidy withdrawals-all demonstrated the farmer need adaptive-strategies to achieve the farmer profit motive. Another analysis is that these farmers are ready and willing to expand output in response to appropriate farmer incentives as the buyer demand arrangements proved. It also shows lack of farmers' own resources to re-invest in agriculture to sustain expanded output. These further demonstrate that a pure subsistence production does not exist among the famers sampled in the Hohoe District.

\section{Food Agriculture Output Marketing Systems}

Two methods of selling farm produce obtained in the District: wholesale and retail. Most farmers sold their produce wholesale as 64 percent respondents indicated while 36 percent retailed. Evidence shows that farmer decision to sell their farm produce and the

2 The implementation of FCUBE guaranteed free access to school and consequently reduced the size of household reproductive labour available for farm work. This in combination w ith the other factors led to the emergence of hired labour in subsistence food production. 
selling methods in the District were often consequences of three different convergent conditions at harvest time. These were anxious need for money at harvest time, storage need and type of farm credit obtained. Harvest time usually presented farmers with two uncompromising choices swaying farmer decisions on produce sale: the compelling need for money and difficulty in managing post-harvest storage. The contention is that most farmers lived from hand-to-mouth and so usually got desperate for money (70\%) to obtain other non-farm goods for subsistence. Also worrying was post-harvest management problems which most farmers (25\%) tried to avoid ${ }^{3}$ and type of farm credit obtained (5\%). These mutually reinforcing conditions jointly created need for quick farm produce turnover at harvest time. This finding confirms the post-harvest 'distress' sales Leavy and Poulton (2007) indicated. Informal interview with some of the private market traders also identified similar concerns revealing their interest in rapid stock turnover, thus, preferring wholesaling to retailing. Evidence points to urban consumers as those mostly interested in retail measures making retailing a feature of the urban market since most of them bought for home consumption (Dzivenu, 2005). Combination of these conditions and others faced by the farmers converge at harvest time to rule the selling and buying methods.

Consequential to these is the general farm produce glut experienced at harvest time depressing producer prices engendering scarcity at planting or just before next harvest (Coulter \& Poulton 2001). For example, in the immediate post-harvest months of November-January in 2002/3, one lonka, that is, an American tin of rice sold between GH\$1.5O and GH\$2.00. However, by May-July of 2003, same quantity of rice sold between GH\$2.60 and GH\$3.50. Thus, the producer prices were low at harvest time and high at planting season. At Gbi-Wegbe, for example, only three percent of respondents had farm produce to sell by planting season, May-July, while 97 percent only had reserves for household use. Also contributing to the uncertain producer prices was three interacting conditions. First, the subsistence food producers were many; second, they operated in a competitive market; and third, their farm produce faced inelastic demand curve. With the produce facing an inelastic demand curve, the producers in food crop markets had no influence over ruling market prices. Hence, any farmer attempt to sell above the going market prices necessarily results in the buyer buying from alternative farmer sources reducing food croppers to mere price-takers (Harrison, 1993).

Also noteworthy is that food marketing system in Hohoe District involved collocation or coming together of both sellers and buyers of farm produce to a chosen place. The designated place was often the village marketplace, individual farm-gates or houses or even pathways - just whenever and wherever - buyers would meet farmers to buy the farm produce. Collocation in this way allowed the buyers personal inspection of the produce and inspired personal exchange relations critical for initial price formation and

3 Post-harvest management was a major problem throughout the District. Though farmers managed to store up their own off-farm season food requirements, these were just large enough quantities to last them till the next harvest. Most of them used traditional silos ewlo or etoe for rice and maize respectively and were generally small and barely efficient. 
fixing producer price levels (Ellis, 1992). Imperative in collocation was the collocation of both sellers and buyers at the place designated in their minds as market to transact. Thus, though collocation allowed buyers personal inspection of produce, the spatial movement it occasioned had hardly affordable extra cost implications for the already cash-constrained famers. Consequently, both for farmer convenience and cutting high produce transportation costs induced by the bad access roads, 96.4 percent of respondents preferred buyers coming to individual farm-gates or houses. Only about four percent were indifferent.

One other limitation of the rural food markets was information asymmetry. Constituting the main buyers in rural food markets were private market traders making up go percent and urban consumers forming 10 percent. Cash-constrained and faced with post-harvest management worries; the immediate farmer need was selling the farm produce. As found out, only the private market women had the latest producer price information and were the only ones ready and willing to bear the risk of high transaction costs. This endorses the information asymmetry argument by Minot (2011). Acutely aware of farmer needs at harvest time, these private traders dictated the selling measures and methods. Thus, farmer knowledge or lack of price information was not a factor in forming and fixing the producer prices. As 95.3 percent of respondents argued, farmer knowledge of latest producer price information was irrelevant as the needs convergence in the circumstances was to sell and to buy. Absence of these variables in the producer price determination coupled with the level of trader risk taking created monopolistic opportunities for de facto monopsonies and monopolies in the rural food crop marketing system. While this supports the findings of Poulton et al. (2005), it also negates the classical arguments that 'natural' monopolies do not exist in agricultural markets (Hubbard \& Smith, 1996). Thus, these market women were in reality local market monopolies and monopsonies; hence, the classical argument has limitations.

Furthermore, the rural food markets were both fragmented ${ }^{4}$ and differentiated with varying degrees of market patronage. To illustrate, peri-urban markets like Gbi-Wegbe and Ve-Koloenu being closer to the district capital benefited from spatial biases (tarmac, urban and roadside). For that matter, they were easily accessible and so both had more patrons than the rural-rural markets in Leklebi-Agbesia and Fodome-Xelu. Two reciprocally interacting circumstances produced this outcome: geographical distance and bad rural access roads. Geographical distance separated these rural markets from one another. Though linked up by rural access road network, their bad conditions stressed the separation with results that the rural food markets operated in seemingly autonomous way. Each market was uncoordinated and functioned independent of the other. While this implies market availability, it also alludes to absence of markets with strong institutional support services to enhance farmer productivity and secure farmers partly against

4 The author observed that every rural, peri-urban or urban settlement visited had a designated marketplace. 
risk. Thus, the food marketing system in the District was in this case not coordinated, regulated or institutionalised and so not remunerative.

With the removal of farm credit subsidies, most subsistence farmers in the Hohoe District self-financed their farming activities as 96.7 percent of respondents indicated. Only about four percent sought credit from other sources. These include bank loans, about two percent, market women/customers, (o.3) and susu groups or micro-credit programmes (1.3\%). Constituting direct loan from customers was a form of loan-assistance dubbed buyer-demand loan. Buyer-demand loans entailed some contractual arrangements with the private market women granting financial assistance to food producers to stimulate production of specific customer-preferred food crops. While 69.7 percent of respondents benefited from the loan and expanded acreage under cultivation, 70.3 percent increased output purposely to meet specific buyer demands. The expanded output was clearly for meeting buyer-driven needs. The evidence confirmed that though most respondents (90\%) considered farming as business, resources to re-invest in it to create desired prospects for food agricultural growth were manifestly lacking.

Favoured in the buyer-demand loan arrangements was wholesale selling and buying for fear of farmers side-selling to other roving traders and avoidance of post-harvest worries. In the peri-urban community of Gbi-Wegbe, where a trader delayed or opted for retailing, the farmer sold all the produce to other itinerant traders at going market prices endorsing Minot's (2011) finding in Rwanda. Also notable was that the side-selling decisions by the farmers were informed by the buyers' refusal to buy the produce at going market prices. Although the study did not expose any usurious interest rates, loan repayment was in kind and calculated according to buyer-dictated farm-gate prices rather than at current market prices. Discrepancies between farm-gate prices and going market rates are issues of imbalanced power relations as Hutchful observed (Hodson, 1983 cited in Hutchful, 2000). An informal enquiry proved that buyer-demand loans were loaded with buyer tendency to exploit farmer vulnerability as the buyers decided both selling methods and producer prices. Without going into all of its variants, farmers only took whatever was left after buyers deducted their credit from total sales ${ }^{5}$. The absence of the necessary price supports only enables such contrived mechanisms to appropriate farmer surplus (Dzivenu, 2005). Nonetheless, with no other alternatives, the buyer-demand loan arrangement provided farmers with the much-needed ready market outlet and effectively offered the best farmer-incentive to expand output.

Though 94.7 percent of respondents claimed that the agricultural subsidies removal negatively affected their farming activities, 74 percent recorded significant increases in output of maize, rice and cassava. Even at national level, production output for the selected crops steadily increased despite subsidy removal and low producer prices in the economy during the period under study. The decision by farmers in the Central Region to demonstrate against the low producer price of cassava-GH $\$ 15$ per ton-for example, demonstrates the pervasiveness of low food producer prices at the time (Dzivenu 2005;

5 This often spells bad news in bad harvest. 
The Independent 2003). That the prevailing poor producer prices did not result in declining output goes against the conventional wisdom and ruled out producer price as key farmer incentive. The inference is two-fold. First, the evidence suggests that producer prices are not prime farmer incentives in subsistence food crop production. As observed, high producer prices in food agricultural output markets inevitably produce negative externalities on society and governments are usually averse to it (Coulter \& Poulton, 2007).

Second, the survey signalled other socio-economic factors as the more potent inducements to food crop productivity. These include provisioning for household food needs $(60 \%)$, crop marketing opportunities (20\%), crop suitability to ecological environment (6.3\%), farmer perception of risk ( $2 \%)$, ease of crop cultivation $(1.4 \%)$ and crop production cycle (1.3\%). Only nine percent of respondents stated producer price as a concern. The findings hold domestic self-provisioning as the main motive for engaging in subsistence farming activities. Supporting this argument, 94 percent of respondents produced mainly for auto-consumption and reproduction. They further established that that they produced enough food to last them till the next harvest. This gives credence to the argument that whatever they sold did not necessarily represent a marketed 'surpluses' but a compulsory requirement to meet family financial needs. Besides, the expanded output did not result from new technology use as only 12 percent of respondents adopted any new output enhancing technology. They blamed the low technology adoption rate on farmer cash constraint. As it were, the remaining 88 percent of respondents expanded acreage under cultivation by extensification. Implied is that the increases recorded in the District resulted from farmer efforts at household self-provisioning and need-adaptive strategies to meet specific buyer-demand needs required to supplement household income. In which case, other socio-economic factors were the powerful stimuli and not the assumed farmer price incentives.

\section{No Food Agricultural Market}

As 88.3 percent of respondents said, inefficient output marketing system was the major constraint on farmer income in the District. The claim for 'no market' to sell the 'little extra' was particularly critical for rice and cassava as was disclosed at a framer rally at Have-Gagbefe ${ }^{6}$. Rice producers even claimed they had government assistance in the production but could not sell whatever they produced to enable them pay back the loan. As Hazel (2007) argued, the locally produced rice could not compete with the cheaper imported one. What this demonstrates is absence of spot markets to match supply to demand, suggesting a flawed situational analysis in formulating the strategy and choice of policy. The reforms only presumed and ignored micro-level farmer needs, priorities and expectations and erroneously assumed a non-existent efficiently functioning liberal commercial practice readily available for food crops (Cleaver, 1993). Also failed in the neo-

6 The farmer rally was held on 27 March 2003. 
liberal strategy choice was the supposed spontaneous functioning of local food markets in step with their own internal logic without government intervention (Gilpin, 1995).

Though 83 percent of respondents acknowledged absence of output market for farm produce as major farmer disincentive, the farmers could not agree on a common approach to solving the market problem. At a farmer rally at Nyagbo-Gagbefe, the variability in food crop types grown showed a high degree of internally differentiated subsistence farmer groups in the District. This created opposing farmer occupational interests, which made reaching any consensus difficult. Rice producers, for example, showed interest only in rice-related issues and so did the other food croppers. As the area was cassava-specific, the general complaint was no market for the acres of cassava ready for harvesting. The rice producers feeling left out also came up with their worry. Their issue was about the special assistance government provided rice growers to boost rice production but offered no market outlet. Worried that the last harvest was unsold to repay the loan and another planting season was near, these farmers were hostile to others talking about cassava. The differences in their occupational interests resulted in farmers not speaking with one voice to effect changes in their circumstances and opening them up to exploitation by the private market women.

\section{Marketing Bias}

Government involvement in output distribution in the District took the form of price information provision services instituted through MoFA. The MoFA field staff assembled information on major food crop price differentials in major producing centres of each district. Such information was made freely accessible by communicating it to all regional and national coordinating centres. This was later broadcast by the media (radio, television and newspapers) to market operators on weekly basis. Though the service was national in character, it had both explicit and implicit connotations. On one hand, it explicitly helped ensure efficient marketing system based on valid produce price information. On the other hand, it only implicitly served the narrow interests of the itinerant private market women, constituting 90 percent of the buyers of the farm produce. It is important to note that it is these market women who moved farm commodities from rural farm communities to major urban centres. Thus, being aware of the existing food price differentials, they simply used it to set the farm-gate prices at various farm produce centres and varied the producer prices by location.

As such, the information on price differentials did not benefit subsistence smallholder farmers in rural areas with bad access roads. For instance, the bad conditions of the access roads made cost of farm produce transportation especially cassava unaffordable to producers creating room for risk-takers, the private traders. Though rural-rural settlements like Akpafu-Odomi (13km), Leklebi-Agbesia (35km), and Fodome-Xelu (8km) were variously linked to the main urban Hohoe market, the linking access roads were in bad conditions. Notwithstanding their proximity, knowledge of price differentials 
or lack of it was immaterial in the producer price determination. As emphasised by $83.3 \%$ of respondents, the bad conditions of the rural road network critically played up the geographic separation and fragmentation of rural markets. Taking advantage of the farmer situation, the itinerant market women rather used the knowledge of the existing price differentials to set farm-gate prices at the various farm-gates. As $95.3 \%$ of respondents said, the itinerant traders rather than the market mechanisms set the produce price, dictated the measure and selling methods. That the farmers were acutely aware of their exploitative situation is certain as one of them vividly summed it up: 'We only toil for these market women and then look on helplessly while they benefit at our expense'. In this context, the rural markets in the District lacked the necessary exchange relations to direct food produce price formation and determination. The lack of exchange relations made the rural markets in the District imperfect and incomplete. These findings sustain our position that rural agrarian markets were incomplete and non-functional weakening the food agricultural component of the macro-reform.

Of significance is that farmer-geographic locations also determined the producer prices. As evidenced, peri-urban farmers living in linear settlements like Gbi-Wegbe and VeKoloenu with their spatial biases and proximity to the main Hohoe market had ready market for their produce and sold them at urban rates. Consequently, producer prices for the various food crops varied by geographic location and differed inversely benefiting the peri-urban farmers as food prices were cheaper in rural areas than what obtained at urban centres. The paradox is that rural farmers who obtained their farm inputs at higher costs rather sold farm outputs at cheaper rates. Deciding the inverse price differentials was the farmer's geographic location translating into whether the farmer was located away from the main road or urban market and condition of the linking feeder roads. Such that food crop input and output prices differed inversely from one rural community to the next and from one traditional area to another. To demonstrate this effect, the price of compound fertiliser (NPK) was GH $\$ 12.80$ in Accra and GH $\$ 13.50$ in Hohoe, 140km from Accra. At Akpafu-Odomi, $13 \mathrm{~km}$ from Hohoe, the same product sold for GH $\$ 15$ and GH $\$ 18.20$ at Leklebi-Agbesia some $35 \mathrm{~km}$ away from Hohoe. Similarly, the food output market sold one lonka of maize for $\mathrm{GH} \$ 2$ at the main Hohoe urban market but the same measure sold for GH $\$ 1.50$ at Akpafu-Odomi and GH $\$ 1.20$ at Leklebi-Agbesia. Implying that throughout the District, the farther away a farmer was from the district capital or the urban market centre, the higher the farm input prices but the lower the farm output prices.

\section{Market Efficiency}

Underlying the reform package was the assumption that markets constitute the most efficient means for organising economic relations. The implication is that the market would allocate the sectoral resources more efficiently. In response to whether the reforms created greater access to market and ensured fairer producer prices, 94.7 percent of respondents disagreed about five percent agreed, and o.6 percent had no idea. Arguing that the reforms did not generate greater access to markets to create farmer incentives, 
83 percent of respondents said there were no markets to sell their produce. The argument is that the marketing system in the District was rather inefficient in organising economic relations and so a disincentive to higher productivity. For instance, the local food crop producers could not sell their 'little extra' to participate in the local economy. In the case of rice, the 'little extra' produced could not compete with the imported rice flooding their local markets. During the period under study, price of locally produced rice ranged between $\mathrm{GH} \$ 23$ and $\mathrm{GH} \$ 30$ for a 5okg weight, while price of imported rice varied between GH $\$ 15$ and GH $\$ 20$ for same weight. As it turned out, the consumers found the imported rice cheaper and more appealing, resulting in no market for the locally produced rice.

Remarkable is that producer price incentives work well in highly institutionalised and complete marketing systems as evidenced by the cocoa sector. For example, in the early 1980s, cocoa production was as low as 15, 900 metric tonnes (mt). However, as the producer prices for cocoa increased, production output progressively increased. For example, between 1981 and 1995, the producer price for cocoa increased 12 times. It rose from GH $\$ 4$ in 1981 to GH $\$ 30.80$ in 1994/95 and was GH $\$ 56.25$ in 2003/3004. Production output similarly increased from the low $15,900 \mathrm{mt}$ in $1983 / 84$ to $300,000 \mathrm{mt}$ in $1994 / 95$ season and 736, ooomt in 2003/2004 and now hitting over a million metric tonnes by 2005 (Dzivenu, 2005). This means that price policies generate stronger income effects for cash croppers. It also proves that price incentives operate where market exists and are impotent without market. As it were, the price incentives did not generate a matching stronger income effects for subsistence smallholder food producers as with cocoa producers having ready institutionalised markets. With the result that 93.7 percent argued that the policy reform did not benefit them. Only 3.6\% said it afforded them better prices and about three percent were indifferent.

\section{Conclusion}

The paper showed that though increasing agricultural output prices is a necessary condition to enhance farmer productivity and food security, it is ineffective without delimiting other productive assets. The paper argued that a sustained expanded food production output is a function of demand and supply. Thus, a critical incentive to a sustained expanded food production output is a continued increase in demand. It implies that to make food agriculture an effective poverty reduction tool requires both medium and long-term state-led investments in processing and food market outlet development.

As found out in this paper, the poor access road networks linking the geographically isolated subsistence food producers and the unorganised food markets constrained the food production output. Market efficiency is a decisive factor to both smallholder producers and consumers along the marketing chain in stimulating demand and supply. However, the poor road transport linkage and inefficient marketing systems mutually created incomplete rural food marketing systems, a significant disincentive to growth and development of food agriculture. The paper consequently holds the view that price 
incentives work better in complete food agricultural marketing systems. For without that market, price incentives are impotent. As evidenced by the cocoa sector, price incentives operate efficiently in institutionalised or complete marketing systems. Thus, what actually depressed farmer incentives were the limited food crop marketing options available to the rural food croppers and absence of investments in rural food markets. As it were, the reform package was flawed on its situational analysis as it did not identify subsistence food crop markets as priorities and only presumed their existence. The findings also emphasised the argument that the role of the state in an economy may diminish but cannot be eliminated as proved in more fully developed western agricultural markets. Thus, enhancing food agricultural productivity must necessarily go concurrently with development of food agricultural markets.

\section{References}

Bates, R. H. (1981). Markets and States in Tropical Africa: The Political Basis of Agricultural Policies Berkeley: University of California Press.

Cleaver, K. (1993). A strategy to Develop Agriculture in Sub-Saharan Africa and A Focus for the World Bank: Draft for Discussion, Technical Departmental Africa Region. Washington DC: The World Bank.

Coulter, J \& Poulton, C. (2001). Cereal Market Liberalisation in Africa. In T. Akiyama, J. Baffes, D. F. Larson \& P. Varangis (Eds) Commodity Market Reforms: Lessons of Two Decades Washington, DC: World Bank, 191-255.

Dzivenu, T. (2005). The Politics of Agricultural Policies and Programmes in Ghana, 19822002. Unpublished doctoral thesis, Legon: University of Ghana, Department of Political Science.

Ellis, F. (1993). Peasant Economics: Farm Households and Agrarian Development Cambridge: Cambridge University Press.

Gilpin, R. (1995). Three Ideologies of Political Economy. In Jr. Kegley \& C. W. E. R. Wittkopf (Eds) The Global Agenda: Issues and Perspectives. New York: McGraw-Hill.

GLSS 4 (2000). Ghana Living Standards Survey: Report on the Fourth Round Accra: Ghana Statistical Services.

Ghana Government (2000). Ghana Vision 2020: The First Medium-Term Development 1997-2000 Accra: NDPC).

Hazel, P. (2007). The Role of Agriculture in Pro-Poor growth in Sub-Saharan Africa. In M. Harsmar |(Ed) Agricultural Development in Sub-Saharan Africa. Workshop Proceedings 8-9 March 2006, Frosundavik, Sweden. 
Harrison, B. (1993). Introductory Economics Course Companion. London: MacMillan

Harrison, G. (2005). The World Bank, Governance and Theories of Political Action in Africa. British Journal of Politics and International Relations 7 (2) pp. 240-26o.

Hutchful, E. (2002). Ghana's Adjustment Experience: The Paradox of Reform (UNRISD). Accra: Woeli.

Leavy, J. \& Poulton, C. (2007, September) Commercialisation in Agriculture. Working paper 003 prepared for Future Agricultures, http:/www.future-agricultures.org

Minot, N. (2011, April). Contract Farming in sub-Saharan Africa: Opportunities and Challenges. Paper prepared for the policy seminar: 'Smallholder-led Agricultural Commercialisation and Poverty Reduction: How to Achieve It?' 18-22 April 2011, Kigali, Rwanda.

MoFA (2007). Food and Agriculture Sector Development Policy (FASDEP II). Accra: MoFA

MoFA (2009). Agricultural Sector Plan 2009-2015. Accra: MoFA

MoFA (2010) Agriculture in Ghana: Facts and Figures. Accra: MoFA

Moore, M. (1985). The State and Peasant Politics in Sri Lanka. Cambridge: Cambridge University Press.

Moore, M. (1993).Economic Structure and the Politics of Sectoral Bias: East Asian and Other Cases. In A. Varshney (Ed) Beyond Urban Bias London: Frank Cass.

Nwanze, K. E. (2010). Cutting the Knot of Poverty and Hunger. Speech delivered by the IFAD president on 23 July 2010 on his visit to Lusaka, Zambia.

Poulton, C, Dorward, A. \& Kydd, J. (2005, June). The Future of Small Farms: New Directions for Services, Institutions and Intermediation. Paper prepared for the Future of Small Farms Workshop 26-29 June 2005, Imperial College, Wye, UK.

Poulton, C, Kydd, J. \& Dorward, A. (2006). Overcoming Market Constraints on Pro-Poor Agricultural Growth in Sub-Saharan Africa. Development Policy Review, 24 (3): 243277.

Riley, H. M. \& Staatz, J. M. (1993). Food System Organisation Problems in Developing Countries. In J. Abbot (Ed) Agricultural and Food Marketing in Developing Countries: Selected Readings Trowbridge, Wiltshire: Redwood Books.

Sarris, A., Savastano, S. \& Christiansen, L. (2006). The Role of Agriculture in Reducing Poverty in Tanzania: A Household perspective from Rural Kilingmanjaro and Ruvuma. FAO Commodity and Trade Policy Research Working Paper, No. 19, Rome: FAO. 
Sikod, F. (2003, November). Policy and institutional incentives for smallholder farmer adoption technologies for sustainable production. In E. A. Atayi \& D. O. Ladipo (Eds) Strategies for Farming Systems Development in sub-Saharan Africa. Proceedings of a workshop on 'Strategies for Farming Systems Development' held at International Institute of Tropical Agriculture (IITA), Ibadan, Nigeria, 17-20 November 1998. Ibadan: Daybis Ltd.

The Independent (2003). 'Central Region Farmers to Demonstrate' Tuesday, 22 July 2003, p.1.

van der Geest, K. and Dietz, T. (2004). A Literature Survey about Risk and Vulnerability in Drylands with a Focus on the Sahel In A. J. Dietz, R. Ruben \& A. Verhagen (Eds), The Impact of Climate Change on Drylands, with a Focus on West Africa. Dordrecht/ Boston/ London: Kluwer, Academic Publishers. Environment and Policy Series, Vol. 39, pp. 117-146.

World Bank (2008). The Political Economy of Policy Reform: Issues and Implications for Policy Dialogue and Development' Operations Report No. 44288-GCB Washington, DC: World Bank. 